\title{
iPosture: The Size of Electronic Consumer Devices Affects our Behavior
}

\section{Citation}

Bos, Maarten W., and Amy J.C. Cuddy. "iPosture: The Size of Electronic Consumer Devices Affects our Behavior." Harvard Business School Working Paper, No. 13-097, May 2013.

\section{Permanent link}

http://nrs.harvard.edu/urn-3:HUL.InstRepos:10646419

\section{Terms of Use}

This article was downloaded from Harvard University's DASH repository, and is made available under the terms and conditions applicable to Open Access Policy Articles, as set forth at http:// nrs.harvard.edu/urn-3:HUL.InstRepos:dash.current.terms-of-use\#OAP

\section{Share Your Story}

The Harvard community has made this article openly available.

Please share how this access benefits you. Submit a story.

\section{Accessibility}




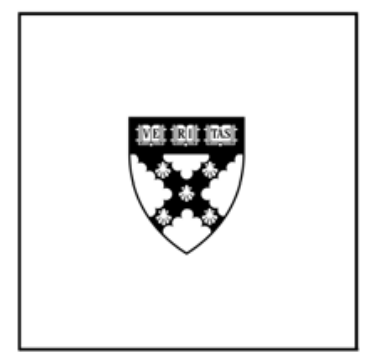

\title{
iPosture: The Size of Electronic Consumer Devices Affects our Behavior
}

\author{
Maarten W. Bos \\ Amy J. C. Cuddy
}

\section{Working Paper}

13-097

May 20, 2013 
iPosture: The Size of Electronic Consumer Devices Affects our Behavior

Maarten W. Bos and Amy J. C. Cuddy

Harvard Business School

Number of words main text: 1004 minus 23 for the figure legend

Number of words abstract: 120

Address for correspondence: Maarten Bos, Harvard Business School, Baker Library 467, Boston, MA 02163, USA, mbos@hbs.edu. Amy Cuddy, Harvard Business School, Baker Library 449, Boston, MA 02163, acuddy@hbs.edu. 


\begin{abstract}
We examined whether incidental body posture, prompted by working on electronic devices of different sizes, affects power-related behaviors. Grounded in research showing that adopting expansive body postures increases psychological power, we hypothesized that working on larger devices, which forces people to physically expand, causes users to behave more assertively. Participants were randomly assigned to interact with one of four electronic devices that varied in size: an iPod Touch, an iPad, a MacBook Pro (laptop computer), or an iMac (desktop computer). As hypothesized, compared to participants working on larger devices (e.g., an iMac), participants who worked on smaller devices (e.g., an iPad) behaved less assertively - waiting longer to interrupt an experimenter who had made them wait, or not interrupting at all.
\end{abstract}


Just before walking into a meeting, many of us are hunched over our smart phones, reading and responding to emails, and reviewing last minute notes. Following this frenzied attempt to efficiently manage our time, we have to be on our game in the meeting. Recent research documenting the benefits of adopting expansive (vs. contractive) body postures - "power posing" - suggests that hunching over our smart phones before a stressful social interaction, like a job interview, may undermine our confidence and performance during that interaction.

Powerful postures both reflect and reinforce power. Specifically, adopting highpower poses (expansive, open) vs. low-power poses (contractive, closed) for just two minutes increases people's feelings of power and willingness to gamble, raises their pain threshold, improves their performance in job interviews, increases their testosterone (associated with fearlessness and dominance; Mehta \& Josephs, 2010; van Honk et al., 1999) and decreases their cortisol (associated with stress; Segerstrom \& Miller, 2004) (Bohns \& Wiltermuth, 2012; Carney, Cuddy, \& Yap, 2010; Cuddy, Wilmuth, \& Carney, under review; Huang et al., 2011). In short, power posing affects an individual's feelings, thoughts, behaviors, and even hormone levels in ways that are normally observed in individuals who possess power (Sherman et al., 2012; Mehta \& Josephs, 2010; Smith \& Galinsky, 2010).

We investigated the behavioral impact of incidental body postures caused by interacting with electronic devices. Participants interacted with devices of different sizes, and we measured the effects on two power-related behaviors -- action and assertiveness, and risk-taking - both of which are bolstered by psychological power (e.g., Keltner, 
Gruenfeld, \& Anderson, 2003). We hypothesized that interacting with larger electronic devices, which induce a more expansive body posture, leads to behavior that is associated with higher power than interacting with smaller electronic devices, which induce a more contractive body posture.

Participants and Design

Seventy-five participants (41 females, average age $=22.6$ ) completed the experiment at the Harvard Decision Sciences Lab. Participants received 10 dollars for participating and, based on their choices and chance, could receive up to 4 additional dollars during the experiment. They were randomly assigned to interact with an iPod Touch (size-equivalent to an iPhone), iPad, MacBook Pro laptop, or iMac desktop (details in SOM).

\section{Procedure and Materials}

Before starting the experiment, participants turned off their cell phones and were consented. Next, they were introduced to the device they would be using. Proceeding, participants completed filler tasks designed to engage them with the device. They started with a short, 5-minute survey in Qualtrics (online survey software), in which they rated five pictures of neutral faces on a few dimensions. Power is inherently social, and this task primes a social context (e.g., Carney et al., 2010). After the survey, participants could play a gambling game (Carney et al., 2010). They were given two dollars, and were then asked whether they wanted to play double or nothing with a 50\% chance of winning. Non-gambling participants kept the two dollars. Gambling participants wrote down three numbers from 1 to 6 and then rolled a die. Winners received another two dollars; losers returned two dollars. 
Afterwards, participants continued with the survey on the device. They were presented with a Blackjack game (Galinsky, Gruenfeld, \& Magee, 2003). Participants were shown the dealer's hand (10) and their own hand (16) and were asked whether they wanted another card. After deciding, participants were given a series of questionnaires (see SOM), ending with demographic questions.

After participants completed the survey, the experimenter pointed at a clock in the lab room and told participants "I will be back in five minutes to debrief you, and then pay you so that you can leave. If I am not here, please come get me at the front desk". The participant could see the clock without moving or getting up. The experimenter waited maximally 10 minutes, and recorded whether and when participants came out. Finally, participants were debriefed and paid.

\section{Results}

Gambling. There was no significant difference between conditions for either gambling decision. For the first gamble, this may have been partly due to a ceiling effect: $72.0 \%$ of all participants chose to gamble the $\$ 2, X^{2}(3, N=75)=2.46, p=.483$. In the Blackjack game, $60.0 \%$ of all participants risked to take another card, $X^{2}(3, N=75)=1.80$, $p=.616$

Interruption time. Device size significantly affected interruption time, $F(3,71)=$ $5.10, p=.003, \eta_{\mathrm{p}}{ }^{2}=.177$ (see Figure 1). Participants with smaller devices waited longer than participants with larger devices. Without the 10-minute cap, the effect might have been even stronger. In fact, some participants did not come out of the lab room at all: device size significantly affected whether or not participants ever interrupted the experimenter, $X^{2}(3, N=75)=11.03, p=.012, \eta=.374($ see Figure 1$)$. 


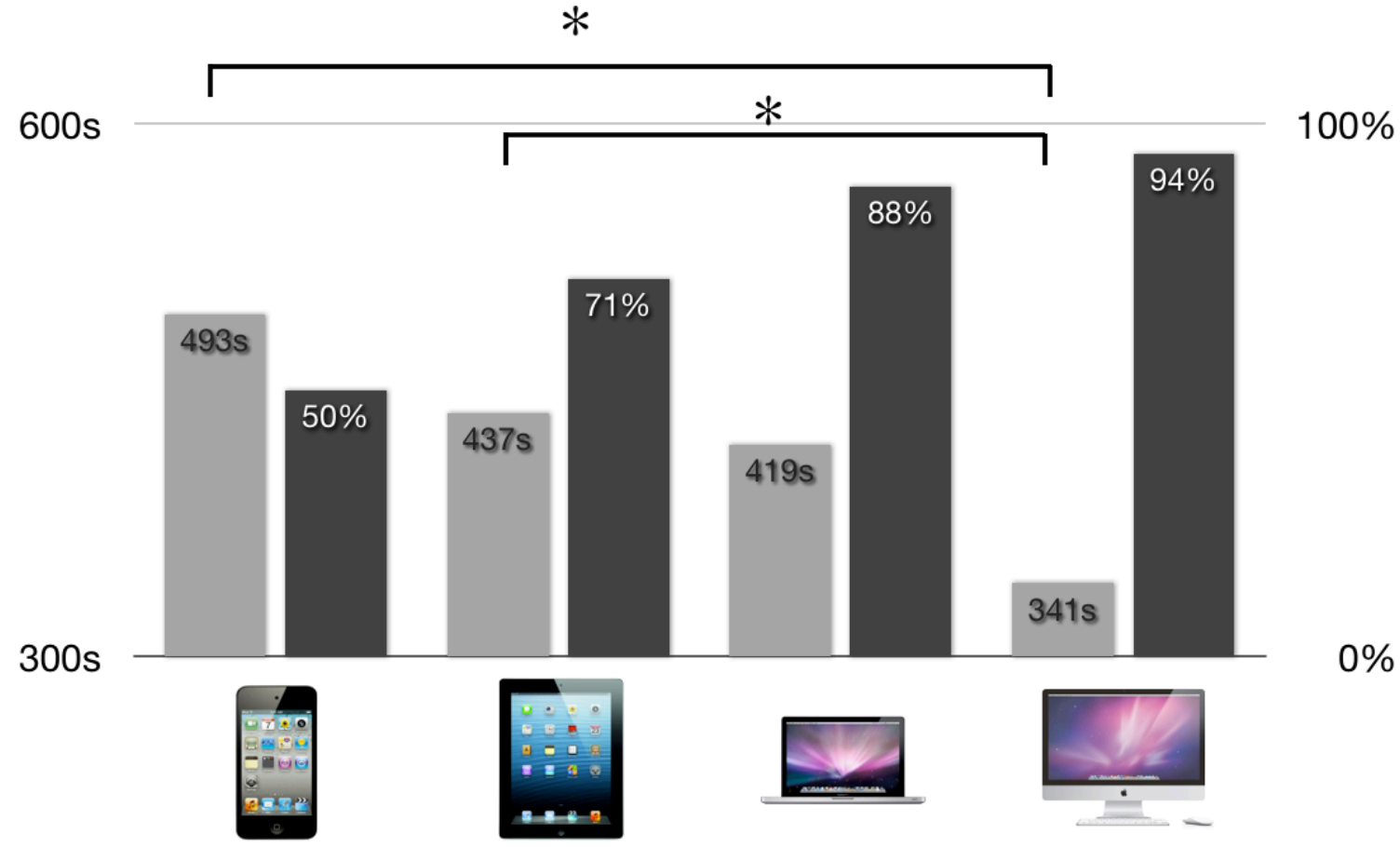

Figure 1. Seconds to interruption in light grey (* indicates $p<.05$ by Tukey posthoc test). Interruption (in percentages) in dark grey.

\section{General discussion}

Interacting with smaller versus bigger devices has an impact on subsequent power-related behavior. Participants interacting with smaller devices were less assertive than participants interacting with larger devices. Consistent with previous findings, we found that expansive body postures - in this case, induced by the size of the device with which one interacted -- lead to more power-related behaviors (Carney et al., 2010; Huang et al., 2011). The effect of expansive or restricted positions may grow stronger over time: Our gambling tasks were presented shortly after participants started interacting with the device, while our assertiveness / interruption task took place at the end. In our study, participants interacted minimally with the experimenter. Future research could investigate how different sizes of devices impacts subsequent interactions. 
Many of us spend hours each day interacting with our electronic devices. In professional settings we often use them to be efficient and productive. We may, however, lose sight of the impact the device itself has on our behavior and as a result be less effective. We suggest that some time before going into a meeting, and obviously also during it, you put your cell phone away. 


\section{References}

Bohns, V. K., \& Wiltermuth, S. S. (2012). It hurts when I do this (or you do that): Posture and pain tolerance. Journal of Experimental Social Psychology, 48(1), 341-345.

Carney, D. R., Cuddy, A. J. C., \& Yap, A. J (2010). Power Posing: Brief Nonverbal Displays Affect Neuroendocrine Levels and Risk Tolerance. Psychological Science 21 (10), 1363-1368.

Cuddy, A. J. C., Wilmuth, C., \& Carney, D. (under review). Preparatory power posing affects performance in job interviews.

Galinsky, A. D., Gruenfeld, D. H., \& Magee, J. C. (2003). From power to action. Journal of Personality and Social Pscyhology, 85(3), 453-466.

Huang, L., Galinsky, A. D., Gruenfeld, D. H., \& Guillory, L. E. (2011). Powerful postures versus powerful roles: Which is the proximate correlate of thought and behavior? Psychological Science, 22(1), 95-102.

Keltner, D., Gruenfeld, D.H., \& Anderson, C. (2003). Power, approach, and inhibition. Psychological Review, 110, 265-284.

Mehta, P. H., \& Josephs, R. A. (2010). Testosterone and cortisol jointly regulate dominance: Evidence for a dual-hormone hypothesis. Hormones and Behavior, $58,898-906$.

Segerstrom, S., \& Miller, G. (2004). Psychological stress and the human immune system: A meta-analytic study of 30 years of inquiry. Psychological Bulletin, 130, 601630.

Sherman, G. D., Lee, J. J., Cuddy, A. J. C., Renshon, J., Oveis, C., Gross, J. J., \& Lerner, J. S. (2012). Leadership is associated with lower levels of the stress hormone 
cortisol. Proceedings of the National Academy of Sciences, 109(44), 1790317907.

Smith, P. K., \& Galinsky, A. D. (2010). The nonconscious nature of power: Cues and consequences. Social and Personality Psychology Compass, 4, 918-938.

van Honk, J., Tuiten, A., Verbaten, R., van den Hout, M., Koppeschaar, H., Thijssen, J., \& de Haan, E. (1999). Correlations among salivary testosterone, mood, and selective attention to threat in humans. Hormones and Behavior, 36, 17-24. 